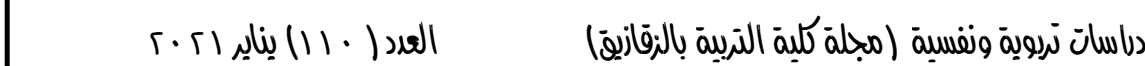 \\ ما وراء المعرفة ومهارات التزجمة الشفوية لطالبات اللفاتوالتزجمة
}

\section{الفورية بجامعة الازهر}

الشيعاء توكل عبد الباري عبد الباري

$$
\text { مدرب لغة انجليزية }
$$

shaimaa3twakal@gmail.com

:الملخص :

هدفت الدراسة الحالية الي تنمية مهارات التحدث للترجمة الشفوية وتقليل حدة القلق لدى طالبات اللغات والترجمة الفورية من خلال استخدام استراتيجية ما وراء المعرفة ـ ولقد اتبعت الدراسة المنهج شبهه التجريبي واستخدمت (60) طالبه من طالبات اللغات والترجمة الفورية بجامعة الازهر، فرع البنات ،محافظة الدقهلية .وقد قسمت عينة الدراسة الى مجموعتين : تجريبيه وضابطه حيث اشتملت المجموعة التجريبية على ثلاثون طالبه والتي درست باستخدام استراتيجية ما وراء المعرفة ، ثلاثون طالبه للمجموعة الضابطة و التي درست بالطريقة التقليدية ، وقد قامت الباحثة بإعداد كلا من أ) اختبار لقياس مهارات الترجمة الشفوية ، ب) مقياس للقلق وتطبيق كليهما قبليا و بعديا ، وقد اجريت الدراسة خلال الفصل

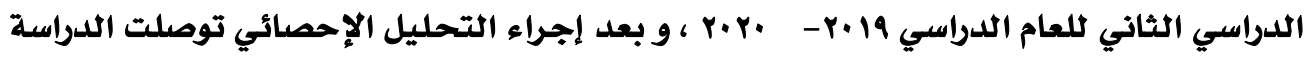
إلى النتائج الآتية ا) وجود فروق ذات دلالة إحصائية بين متوسطي درجات عينة الدراسة ـِ اختبار الترجمة الشفوية قبليا و بعديا لصالح التطبيق البعدي ، ب) وجود فروق ذات دلالة إحصائية بين متوسطي درجات المجموعة التجريبية والمجموعة الضابطة يِ اختبار الترجمة الشفوية قبليا 
وبعديا لصالح المجموعة التجريبية، ج)وجود فرق ذات دلاله إحصائية بين متوسطي درجات

المجموعة التجريبية والمجموعة الضابطة ِِّ مقياس القلق قبليا ويعديا لصالح المجموعة

التجريبية ، د )الاستراتيجية القائمة على ما وراء المعرفة لها أثرا إيجابيا يٌْ تقليل القلق لدى

طالبات اللغات والترجمة الفورية.

\title{
Metacognition and Oral Interpretation Skills for Al Azhar Languages and Simultaneous Translation Students
}

\begin{abstract}
This study aimed to develop the public speaking skills of second year languages and simultaneous translation students and reduce their oral apprehension through using a metacognitive regulation strategy. The current study was conducted during the second term of the academic year 2019 -2020 .The present study followed the pre-post, quasi- experimental - control group design. The researcher used two groups: quasi-experimental and control. A number of sixty second year from Languages and Simultaneous Translation students ,English department, Faculty of Humanities , Al Azhar Universty, Tafahna Al Ashraf, Girls Branch, Al dakahlia Governorate, Egypt were the participants who were randomly divided equally into two groups. An interpretation test was used to measure second year students' public speaking skills before and after the treatment; a sight translation apprehension scale was used




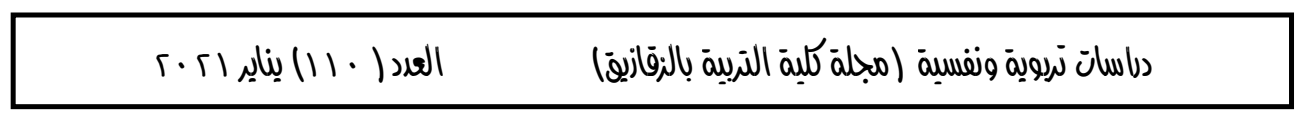

to measure the level of apprehension before and after the treatment adopting a strategy based on metacognition. The results of the study showed that the metacognitive regulation strategy was effective in developing the sight translation public skills and in reducing oral apprehension of second year students.

Keywords: Metacognition, self-regulation, interpretation, sight translation skills, public speaking, oral communication, apprehension

\section{Introduction}

Translation is the core of communication process among different cultures and nations. The translator helps people to navigate in different fields through producing new information and opening new horizons of knowledge. It is considered as a wide item which means delivering written messages and ideas from one language to another .In addition, it includes oral types which called interpretation that deals with both oral and rapid output.

Oral interpretation is a unique kind of translation which used lately in different fields and places such as education ,business and medical institutions. It depends on delivering the message orally at the same time of receiving it. It has three different types represented in simultaneous, consecutive and sight interpretation. Sight interpretation is one of the most important oral ones that has been taught at interpretation institutions and used widely at conferences. 
Weber (1984) considers ST as a good preparation for both consecutive and simultaneous interpretations because it trains students in rapid text analysis, public speaking and avoiding transcoding.

ST is a special style which combines translation and interpretation, as it is a combination of the written aspect (represented by translation) and the oral one (represented by interpretation). As defined by Gonzalez, Vasquez and Mikkelson (2012), sight translation is the act of the oral translation of written text and a combination of translation and interpreting. Angelelli (1999: 27) reported that sight translation should seem as if the interpreter were reading a text in the target language, which includes smooth delivery and natural production avoiding hesitations and irregular pauses.

Ilg and Lambert (1996) see that sight translation is considered as a helpful mean in expanding language transfer and oral skills through the process of reformulating, paraphrasing, summarizing , and restructuring the source text. It has two types which can be separated into rehearsed ST and unrehearsed ST (Lambert, 2004). Rehearsed ST allows the interpreter to have some time to read the text first before going to deliver the message, whereas unrehearsed ST requires the interpreter to sight-translate the written text immediately after it is received. 


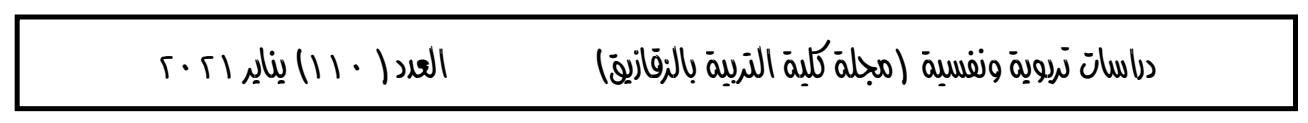

The oral translator should be trained a lot to avoid the difficulties of unrehearsed translation, Weber (1984:33) confirmed that the instructor should observe the translators' skills in the following areas :

- Public speaking qualities presentation, poise, and voice

- Speed

- Clarity and the conciseness of the rendition

Lee (2012) pointed out that sight translation suffers from dearth of studies that affect translators oral output. She sees that instructor should examine interpreters' sight translation performance in accuracy, target language expression and delivery qualities. Angelelli (1999: 27) reported the importance of natural oral production in sight translation, the oral production should seem as if the interpreter were reading a text in the target language in a smooth performance avoiding hesitations and irregular pauses. Along with this point ,Akbari study(2017) asserted that sight translation consisted of both visual and oral forms of information producing; therefore, ST is considered as a particular kind of written text (written input) as well as an alternation of oral interpretation (oral output).

Many researchers affirmed that public speaking skills are a vital element in sight translation successful output, but it is affected by several reasons . Along with this point, Chang (2016) conducted 
a study to find out that the students' performance indicated that the challenges they faced in ST learning and performance were mainly related to insufficient topical knowledge, inadequate vocabulary items, unfamiliar expressions or jargon, and weak expressions which lead to wrong production in the target language. $\square$

Another difficulty discovered by $\mathrm{Lu}$ et al. (2003) who have found that, in Chinese-Spanish ST class, the translators realized the lack of vocabulary items, sentence structures, jargon, the lack of related knowledge, the inability to make associations, and the difficulty in handling numbers as the biggest difficulties which affect the sight translation process. Moreover, Ivars (2008) indicated that student interpreters performing English-Spanish ST considered the problems related to source text comprehension as their main cause of weak performance in ST, followed by the difficulty in finding the target language equivalents. Furthermore, Lee (2012) found that the student interpreters performing EnglishKorean ST, tended to follow closely the structure and style of the source text which lead to literal translation.

McCroskey (1980) and Bond (1984), listed some factors that can lead to a quiet student who will not participate in classroom; these factors are represented in :

- Low of intellectual skills 


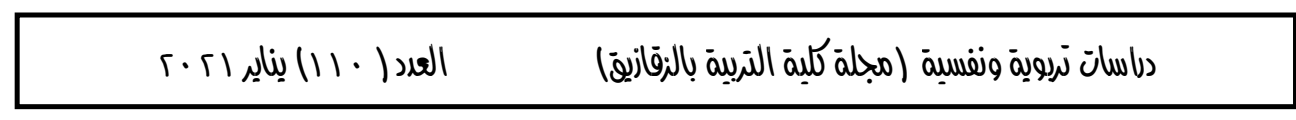

- Lack of speech skills

- Being social introversion

- Communication anxiety

- Low social self-esteem

- Ethnical and cultural differences in communication principles.

As mentioned above, despite the importance of oral and public speaking skills in sight translation, most of interpreters are not qualified or not trained enough to produce natural output . Unqualified interpreters suffer from serious obstacles which lead to deliver the message incorrectly. As a result, interpreters need a group of skills that may enhance their performance.

So, the researcher reviewed the previous studies to find a strategy that may help students to translate better, produce natural and smooth output and overcome their apprehension. Among the previous studies, the researcher found that metacognitive regulation strategy is an effective way in developing English language skills, so the researcher adopted a strategy based on metacognitive regulation to enhance public speaking skills as a main skill in sight translation natural and clear performance .

Metacognition is known as cognition about cognition, or what is called thinking about thinking. According to Flavell (1979:252) 
,the aim of metacognition is to achieve cognitive goals through the continuous regulation and active monitoring of cognitive processes. Metacognitive regulation strategy is consisted of three basic strategy groups represented in planning, monitoring, and evaluating (Chamot and O’Malley ,1994). Planning strategy allows learners to design, plan and arrange their own learning process, while monitoring requires the learner to check their production or comprehension, and evaluating strategy provides learners with analysis , evaluation and judgment of learning the task.

Sight translation is a complicated process which the translator must struggle with the predominance of sudden and unexpected situations to deliver the message clearly. By using a metacognitive strategy, translators through planning can select the suitable method that affect their performance.. Translators also can use monitoring which allows self - testing skills. In addition, translators can evaluate the products and efficiency of their output by reevaluating their previous goals, revising and enhancing their gains. Through the metacognitive regulation strategy, the translator can deliver the meaning smoothly in terms of correct pronunciation, intonation, and pauses. In addition, sight translation is not limited to text comprehension and solely knowing the meaning of words, but the sight translation skills should involve students' skills in evaluating, commenting and making assessment on their performance. Through the process of regulation, sight translators 


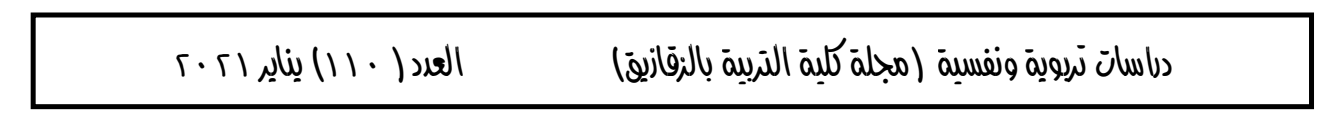

can reach to self-confidence avoiding apprehension and confused voice.

\section{Review of Literature}

\subsection{Sight translation:}

Krapivkina (2018) investigated the challenges and exercises of sight translation in order to overcome the difficulties and improve translators' output. The study used the teacher's assessment and students' self-assessment questionnaire. Participants were consisted of 57 students in the final year at a university in Russia. The results showed that public speaking skills are the most challenging criteria for the students to achieve and the least challenging criteria are to deal with the genre convention and register. He found out that sight translation training should focus on some skills such as clarity and fluency of oral output, the coherence of discourse, linguistic accuracy, compliance with register and genre conventions, appropriate speaking speed rate, timeliness of delivery, appropriate tone, volume, and voice production.

In confirming the importance of oral skills in sight translation ,Nilsen and Monsrud (2015) investigated 'public sector interpreters' reading speed in Norwegian' to show a specific need for training reading skills among public sectors. They stated that interpreting requires well- developed reading skills in addition to 
oral skills. They saw that the main difficulty of sight translation is the weakness of sight translator's skills in reading. It is obvious that the translator's reading speed will influence the flow and the speed of ST, while his reading accuracy will affect the accuracy of the final output of ST. They also affirmed the importance of public speaking and reading skills in both languages.

Matin (2014) reported that sight translation has attracted so much attention from researchers and scholars. In this regard, cognitive aspects of sight translation such as control of mind, and monitoring the oral speech are regarded as more important subjects than grammar knowledge or memory working .

Some studies showed that instructors and translators can get benefit by following some criteria, because such assessment can lead to better performance. According to Akabri Study(2017) who tried to evaluate the performance of four professional and ten student interpreters' sight translations from English (L2) into Persian (L1) on the basis of four criteria such as ' reading speed, delivery quality, accuracy in terms of minor and major errors, and the quality of target language expression'.His study was a guide for both professional and student interpreters to possess the professional skills of sight translation and to reach a professional performance. 


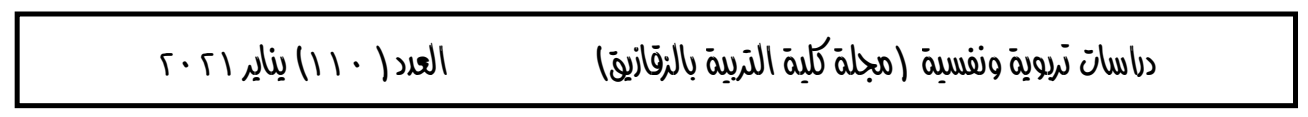

Other criteria were applied by Lee (2008: 168)who provided three core elements for assessing the quality of interpreting performance through 'accuracy', 'target language quality', and 'delivery time' .Riccardi (2002: 121-123) mentioned some microcriteria to estimate professional and students' interpreting performance including prosody deviation, phonological deviation, , production deviation, pauses, eye contact, posture and lexical deviation .

\subsection{Oral apprehension}

Public speaking skills are a vital element to enhance oral translation but it cannot be developed without communication skills .A kind of communication should be found between the text and the translator, and between the translator and the audience from the other side. But there is some sort of psychological barriers which block the process of communication; this barrier is apprehension. Oral communication apprehension has been identified as a major factor which inhibits learners' readiness to communicate and blocks their ability to develop effective communication skills. Amogne and Yigzaw (2013) indicated that apprehension seriously affects how students communicate, and communication is critical to success in academic achievement as well as the practical environments. Communication apprehension is regarded as a kind of shyness

\section{- 285 -}


characterized by fear of or anxiety about communicating with other people (Horwitz, Horwitz, and Cope, 1986). Problems of speaking in public (stage fright) or in groups (oral communication anxiety), or in listening or learning a spoken message (receiver anxiety) are all forms of communication apprehension. It is clear that communication apprehension plays a crucial role in foreign language progress. The students who usually have trouble in speaking in front of groups probably face greater difficulty in speaking in foreign language classes where they have little control of the communicative situation and feel that their performance is constantly monitored (Horwitz et al. 1991).

Another cause of apprehension was added by Aeni et al. (2017) who affirmed that the lack of an extensive vocabulary in English is an important factor in oral communication apprehension. When learners are speaking without background knowledge or many vocabularies associated with a certain topic, they feel unwilling to speak and it leads to communication apprehension. Yahya (2013) emphasized that being in oral communication without readiness, good preparation and extension vocabulary can lead learners to be anxious and more apprehensive.

Idri (2014) also affirmed that fear of negative evaluation is an effective inhibitor of oral communication apprehension. Aeni et al., (2017) added that having a fear of making errors or mistakes leads learners to give up some parts of their oral performance. 


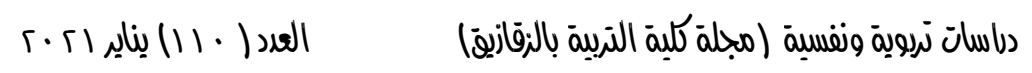

Another cause was reported by Ellis (2005) who stated that having difficulties in oral performance is the most common problem that almost every foreign language speaker faces during the process of language learning. Compared with other language skills such as writing, reading, and listening, speaking or oral communication is the most apprehension causing skill for language learners. Many speakers face some apprehension based on different factors. For example, when someone does not feel adequately prepared or otherwise lacks background knowledge about the topic he feels really nervous and afraid to talk.

Idri (2014) reported several causes of communication apprehension represented in : poor preparation, inappropriate selfexpectations, fear of evaluation, excessive focusing on the topic, and fear of audience's reactions. Taha and Abu Rezeq (2018) examined another cause of apprehension referring that quietness, shyness, and hesitation are general personality traits which extremely cause communication apprehension. Friedman (1980) declared that shyness or silence takes place when the process of verbalizing limits the desire and ability to participate in discussions. The level of shyness or range of situation affects and differs greatly from one learner to another.

Leong and Ahmadi (2017) examined the factors affecting learners' English speaking skills through a theoretical and analytical study .The researchers, after their analysis to many 
studies, concluded that the learner who had higher levels of shyness, anxiety, low self-esteem, and low motivation had serious problems in speaking skill despite their linguistic competence. The study recommended that EFL teachers need to raise their students' self-confidence and motivation to avoid oral apprehension.

Ireland (2016) conducted a study to help students improve their presentation skills. The researcher aimed to produce some effective solutions to reduce $\mathrm{CA}$ in public speaking settings. The researcher used semi-conducted interviews as an instrument. The study revealed that the major causes of fear of public speaking were novelty, performance orientation, learners' characteristics, and traitlike individual differences.

Several studies have been conducted to determine whether learners of foreign language are facing any oral communication apprehension or anxiety as a result of students' interaction with their teachers and other peers at schools and universities. Several studies focused on the causes and effects of oral communication apprehension. Researchers tried to determine if apprehension was anticipated or real. They wanted to find out why apprehension affected students' self-esteem and inhibit their capacity to communicate frequently with others. As a result, communication apprehension (CA) is believed to extend to students' lives (school, friendship, and work) (Holbrook, 1987; Richmond and Mc Croskey, 1995). 


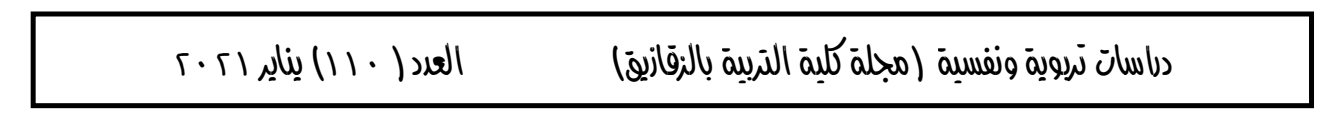

Shedding light on the previous point, Al-Otaibi (2016) attempted to find out the factors of speaking anxiety among EFL Arab freshmen college students in Saudi Arabia. The sample of the study consisted of 22 English-Arabic translation students at King Saud University, Riyadh, Saudi Arabia. The researcher used a $14-$ item questionnaire as an instrument to determine the level of anxiety. The results of the study showed that peer comparison, students' perceptions about their ability to speak, English rules, difficulties in understanding the teacher and impromptu speech were the main aspects that resulted in speech anxiety between students.

Noor et al.,(2015) considered that it is has been proven that language anxiety has become the main cause of many problems that occur in language learning. Language apprehension or anxiety is one of the main elements that define the level of comprehensible input received, it has indeed developed into a prominent factor in determining the success and progress of language learning. Their study attempted to determine students' perception on communication apprehension as well as to identify their level of anxiety. The participants were 113 students from several universities in Malaysia. A questionnaire adapted from the measurement scale of language anxiety named the Foreign Language Class Anxiety Scale (FLCAS) was used. The results 
showed that the majority of the students have a high level of communication apprehension during learning English.

Chen and Chang (2009) investigated the relationship between foreign language anxiety, cognitive load, and task performance. Cognitive load was represented in the load carried by working memory in performing a particular task. Instruments of the study were two scales: the Cognitive Load Subject Rating Scale (CLSRS) to measure the cognitive load while dealing with an English listening task , and the Foreign Language Classroom Anxiety Scale (FLCAS) to determine the students' anxiety level. Participants of the study were 88 non-English major participants, registered in a 4year program at the Technical University in Taiwan. The results of the two scales indicated that students have higher foreign language anxiety higher cognitive load. Therefore, the study affirmed that foreign language anxiety and cognitive load have a negative correlation with listening comprehension.

Toth (2006) discussed the role of foreign language anxiety which happens during the oral production of English in a qualitative study carried out among Hungarian advanced-level learners. The study showed that anxiety affects Hungarian first year English majors' speech production and performance during their conversation with a native English speaker . 


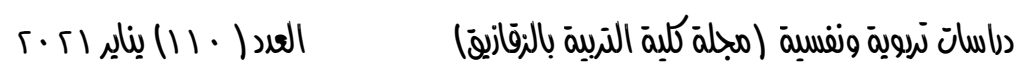

\subsection{Metacognition}

Metacognitive strategies have been proved to play an important role than other strategies in the successful language learning; these strategies facilitate learners to manage, control and regulate their own learning, and effectively support them to perform completely different language tasks in numerous contexts (Pintrih, 2002). Metacognition is described as the knowledge about the regulation of one's cognitive and psychological activities in the learning process (Fravell ,1979; Brown ,1978). Flavell's model (1979: 908), has mentioned metacognition elements and classified cognition itself into three components:

- Metacognitive knowledge/ metacognitive awareness which means what learners know about themselves and others as cognitive processors.

- Metacognitive regulation which indicates the regulation of cognition process and learning experiences through a series of activities that help learners facilitate and control their learning.

- Metacognitive experiences whichimply experiences associate $\mathrm{d}$ with the current mental pursuit. 
In the field of foreign language learning, many studies have been conducted to highlight the role of metacognition aspects and components in language learning; a study conducted by Al-Alwan et al.(2013)reported that metacognition plays a very important role in many cognitive and psychological processes related to language use in oral communication. Their study explored metacognitive listening strategies awareness and its relationship to listening comprehension on a convenient sample of 386 tenth-grade EFL learners.This study used two instruments: (a) Metacognition Awareness Listening Questionnaire (MALQ) and (b) a Listening Comprehension Test (LCT). The results revealed that students have a moderate level of metacognitive listening strategies awareness. It is confirmed that metacognitive strategies awareness is asserted in listening comprehension instruction.

According to Peters (2000) and Rivers (2001), metacognitive skills are important in the development of independent and selfregulated learners. Peters (2000) refers to metacognitive skills as something which enables learners to self-manage, regulate, and evaluate their own thinking and the way of learning. Rivers (2001) affirmed that students' self-directed learning behavior is related to students' regular evaluation of their academic performance, their method of learning, and how this compares with that of other learners and with the teaching styles used. 


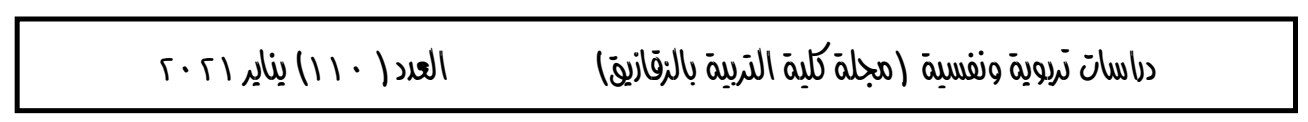

Most studies affirmed that learners who have metacognitive skills and abilities seem to have the following advantages more than others who are not aware of metacognition role in their language learning process:

- They are more strategic learners.

- Their rate of progress in learning, the quality and the speed of their cognitive performance is faster.

- They are confident in their abilities.

- They do not hesitate to request help from peers and teachers when needed.

- They can provide accurate assessments of why they are successful learners.

- They think about problems when a failure occurs during a task.

- Their organization matches the learning task and alternations are made to reflect and suit the changing circumstances.

- They recognize themselves as continual learners and can successfully cope with any new learning situation (Wenden, 1998). 
The use of metacognitive regulatory skills plays a critical role in the cognitive processes of language learning as a mean of communication. According to this explanation, metacognitive strategies are higher order executive skills that include planning for, monitoring, or evaluating activities to manage, direct, regulate, and guide the learning process (O'Malley and Chamot, 1990). Birjandi, Mirhassani, and Abbasian( 2006) regarded metacognitive skills as a mental tool and a symbol of positive learning that takes the seventh sense role.

\section{Statement of the problem:}

Based on the above discussion, it could be stated that second year English department students, Faculty of Humanities Studies, Languages and Simultaneous translation need to develop their oral and public speaking skills as an essential skill in sight translation process. So, this study was an attempt to find an answer to the following main question :

What is the effect of the metacognitive regulation strategy on developing oral speaking skills of second year languages and simultaneous translation students?

This main question could be sub-divided into the following questions: 


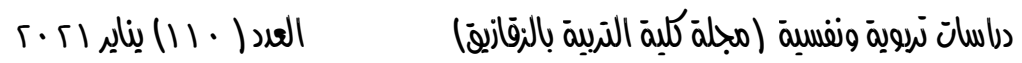

1) What are the oral speaking skills appropriate for second year sight translator students at Languages and Simultaneous Translation English department?

2) To what extent do second year students perform these skills?

3) To what extent does this metacognitive strategy affect oral translation apprehension?

\section{Significance of the study:}

This study can hopefully be useful to :

- Second year students at languages and simultaneous translation English department ,Al Azhar University to:

- develop their oral interpretation and public speaking skills of sight translation process.

- improve their abilities to translate better and overcome their anxiety.

- raise their motivation to practice sight translation widely in different topics.

- Instructors of translation as it may provide them with practical procedures and effective activities to develop their methods in teaching sight translation.

\section{Aims of the study:}

This study aimed at: 
- Developing the public speaking skills at sight translation process of second year languages and simultaneous translation students.

- Reducing second year students' apprehension during the sight translation process.

\section{Delimitations of the study :}

The present study was delimited to:

- A random chosen sample (60) of second year students at the Faculty of Humanities Studies, languages and simultaneous translation English department, Girls branch, Al Azhar University, Dakahlia Governorate.

- The second term of the academic year 2019 -2020

- Some sight translation skills from English into Arabic / Arabic into English. These skills are (public speaking skills ).

\section{Procedures of the study:}

To answer the study questions, the following procedures were carried out:

1) Reviewing related literature related to:

a. Sight translation skills to identify the required skills for the targeted sample.

b. Metacognition to identify the suitable strategies to develop sight translation skills . 


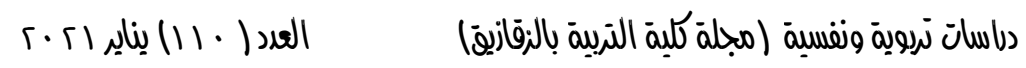

c. Oral communication apprehension to determine its reasons

2) Designing a list of sight translation skills(public speaking )

3) Submitting the sight translation skills checklist to the jury members to determine its validity.

4) Designing sight translation test and a rubric to correct the test.

5) Submitting the test and the rubric to jury members to determine its validity.

6) Selecting the study sample of $2^{\text {nd }}$ year students and dividing them into two groups :experimental and control group.

7) Pre-administrating the sight translation test to the experimental and control group.

8) Designing the experimental framework of metacognitive strategy to develop the identified sight translation skills and teaching it to the experimental group only.

9) Implementing the metacognitive strategy to the experimental group only.

10) Post- administering the sight translation test to both groups (experimental / control).

11) Comparing the results of both administrations of both results.

12) Analyzing the results statistically.

13) Interpreting the results and discussing them. 
Metacognition and Oral Interpretation Skills for Al Azhar

الشِماء توكل عبِ الباري

14) Presenting the conclusion, providing recommendations and suggestions for further research.

\section{Data analysis :}

To determine whether students' sight translation skills have been improved after implementing the experimental treatment using the metacognitive strategy, the hypotheses of the study were tested by using the Statistical Package for Social Sciences (SPSS v.23) Program. T-test was used in order to check whether there is any difference between the mean scores of the treatment group on pre and post- administration.

\section{Verifying the study Hypotheses}

\section{Hypothesis (1)}

The first hypothesis stated that "There is a statistically significant difference between the mean scores of the experimental and the control groups in the post administration of public speaking skills test, in favor of the experimental group".

To verify this hypothesis, the researcher used the Independent sample t-test to compare the mean scores of the experimental group students who used the metacognitive regulation strategy with those of the control group students who used the traditional method, in the post-test. The results are presented in the following table: 


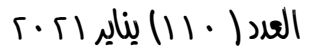

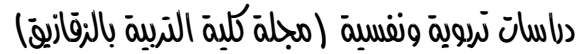

\section{Table (1)}

Differences between both groups in the post sight translation skills test administration

\begin{tabular}{|c|c|c|c|c|c|c|c|}
\hline The Group & $\mathbf{N}$ & $\begin{array}{l}\text { Std. } \\
\text { Error } \\
\text { Mean }\end{array}$ & Mean & $\begin{array}{c}\text { Std. } \\
\text { Deviation }\end{array}$ & $\mathbf{t}$ & Df & $\begin{array}{c}\text { Sig. } \\
(2- \\
\text { tailed) }\end{array}$ \\
\hline Experimental & 30 & .47307 & 40.9000 & 2.59110 & & & .000 \\
\hline Control & 30 & .57801 & 17.6667 & 3.16591 & 31 & 58 & .000 \\
\hline
\end{tabular}

This table indicates that there is a statistically significant difference between the mean scores of the experimental and control group in favor of the experimental group in the post administration of the sight translation skills test, $t$ - value being (31). It is significant at (0.01) level . So the first hypothesis was accepted.

\section{- Hypothesis (2)}

It has been hypothesized that "there is a statistically significant difference between the mean sores of the experimental group in the pre / post sight translation skills test results, favoring the post results" .A Paired Samples t- Test was used to verify this hypothesis as shown : 
Metacognition and Oral Interpretation Skills for Al Azhar

الشبماء نوكل عبر الباري

\section{Table (2)}

Comparing the pre to post administrations of the sight translation skills test of the experimental group

\begin{tabular}{|l|c|c|c|c|c|c|c|}
\hline The Group & $\mathbf{N}$ & $\begin{array}{c}\text { Std. } \\
\text { Error } \\
\text { Mean }\end{array}$ & Mean & $\begin{array}{c}\text { Std. } \\
\text { Deviation }\end{array}$ & t & & $\begin{array}{c}\text { Sig. } \\
\mathbf{( 2 -} \\
\text { tailed) }\end{array}$ \\
\cline { 1 - 5 } Experimental & 30 & .47307 & 40.9000 & 2.59110 & & & .000 \\
\cline { 1 - 3 } & 30 & .57801 & 17.6667 & 3.16591 & 31 & 58 & .000 \\
\hline
\end{tabular}

This table indicates that there is a statistically significant difference between the mean scores of the experimental group in the pre post sight translation skills test results, favoring the post results, $\mathrm{t}$ value being (31). It is significant at (0.01) level . So the second hypothesis was accepted.

\section{- Hypothesis (3)}

It has been hypothesized that "There is a statistically significant difference between the mean scores of the experimental and control group in the apprehension scale results, in favor of the experimental group". An independent samples $\mathrm{t}$ - test was used as shown: 


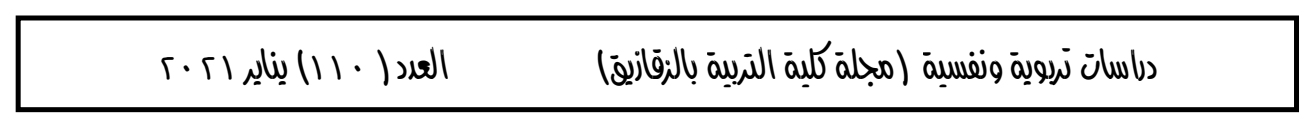

Table (3)

Differences between both groups in the post sight translation apprehension scale

\begin{tabular}{|l|c|c|r|r|r|r|}
\hline \multicolumn{1}{|c|}{ The group } & $\mathbf{N}$ & Mean & $\begin{array}{c}\text { Std. } \\
\text { Deviation }\end{array}$ & Df & $\begin{array}{c}\text { T - } \\
\text { value }\end{array}$ & $\begin{array}{c}\text { Sig. } \\
\mathbf{2 -} \\
\text { tailed) }\end{array}$ \\
\cline { 1 - 5 } $\begin{array}{l}\text { Experimental } \\
\text { group }\end{array}$ & 30 & 19.3000 & 2.40903 & & & \\
\hline $\begin{array}{l}\text { Control } \\
\text { group }\end{array}$ & 30 & 31.1667 & 3.69607 & 58 & 14 & .000 \\
\hline
\end{tabular}

This table indicates that there is a statistically significant difference between the mean scores of the experimental and control group in favor of the experimental group in the post administration apprehension scale, $t$ - value being (14 ) . It is significant at (0.01) level. So the fourth hypothesis was accepted.

\section{- Hypothesis (4)}

It has been hypothesized that" there is a statistically significant difference between the mean sores of the experimental group in the results of pre / post sight translation apprehension scale, favoring the post results".A Paired Samples t- Test was used as shown: 
Metacognition and Oral Interpretation Skills for Al Azhar

الشِماء تَوكل عب البِاري

\section{Table (4)}

Comparing the pre to post administrations of the sight translation skills test of the experimental group

\begin{tabular}{|c|c|c|c|c|c|c|c|}
\hline The group & $\mathbf{N}$ & $\begin{array}{c}\text { Std. } \\
\text { Error } \\
\text { Mean }\end{array}$ & Mean & $\begin{array}{c}\text { Std. } \\
\text { Deviation }\end{array}$ & df & $\begin{array}{c}\text { t- } \\
\text { value }\end{array}$ & $\begin{array}{c}\text { Sig. } \\
(2- \\
\text { tailed }\end{array}$ \\
\hline $\begin{array}{c}\text { Experimental } \\
\text { post-test }\end{array}$ & 30 & .43983 & 19 & 2.40903 & & & .000 \\
\cline { 1 - 4 } $\begin{array}{c}\text { Experimental } \\
\text { pre -test }\end{array}$ & 30 & .66332 & 31 & 3.63318 & & 14 & .000 \\
\hline
\end{tabular}

This table indicates that there is a statistically significant difference between the mean scores of the experimental group in the pre post sight translation apprehension scale results, favoring the post results, $t$-value being (14); it is significant at (0.01) level. So the fifth hypothesis was accepted.

\section{- Hypothesis 5}

It has been hypothesized that " There is a positive effect of the metacognitive regulation strategy on the experimental group in sight translation apprehension scale “. Cohen's (1988) equation was used to verify this hypothesis as shown:

$d=\frac{M 1-M 2}{\sigma}$ 


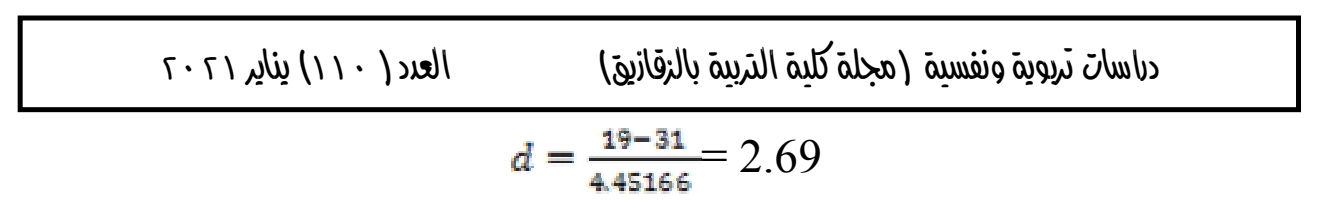

To test the validity of this hypothesis, Cohen's equation was used for the sight translation apprehension scale as whole as follows:

Table (5)

\begin{tabular}{|l|l|}
\hline Effect size & Interrelation \\
\hline From 0.2 till less than 0.5 & Small \\
\hline From 0.5 till less than 0.8 & Medium \\
\hline From 0.8 or more & Large \\
\hline
\end{tabular}

According to the findings of the Cohen's equation, the effect size of metacognitive strategy on reducing sight translation apprehension:

Table (6)

\begin{tabular}{|l|c|c|c|}
\hline $\begin{array}{l}\text { Students' sight } \\
\text { translation } \\
\text { skills }\end{array}$ & N & D & Effect size \\
\hline Total & 30 & 2.69 & Large \\
\hline
\end{tabular}

According to the findings of Cohen's equation, this percentage (2.69) indicates that the metacognitive strategy had a positive effect on reducing sight translation apprehension. Therefore, it provided valid evidence to support the sixth hypothesis. 


\section{Results of the study:}

The results of the current study revealed the following :

1- The experimental group outperformed the control one in the post administration of the sight translation sub skills test (public speaking).

2- The experimental group did better in the post administration of the sight translation skills test in its sub skill (public speaking skills).

3- The metacognitive regulation strategy could be considered effective in developing the public speaking skills.

4- The experimental group outperformed the control one in the post administration of the sight translation apprehension scale.

5- The experimental group did better in the post administration of sight translation apprehension scale.

6- The strategy based on metacognitive could be considered effective in reducing sight translation apprehension .

\section{Discussion:}

These significant improvements in the experimental group' performance are attributed to many reasons related to the nature of the strategy based on metacognition which can be shown as follows: 


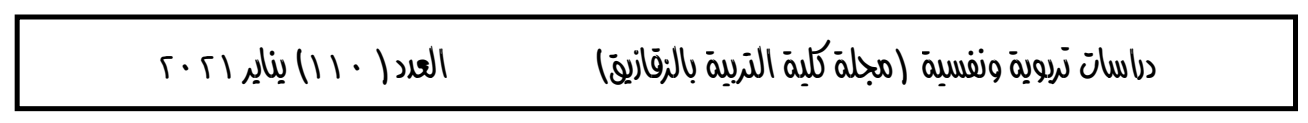

- Providing the participants with different translation tasks and activities that enabled them to get more exposure to sight translation skills.

- Providing the participants with many different opportunities to practice sight translation more.

- Enabling the participants to regulate and evaluate their tasks.

- Providing the participants with the facility to express themselves through giving and receiving corrective feedback about their translation .

- Motivating the participants through utilizing various and different methods which reduced apprehension.

- Increasing the participants' ability to reduce their apprehension and produce a natural and a creative output.

\section{Recommendations}

In the light of the current study results, conclusion and the pertinent literature, the following recommendations could be provided for translation instructors :

- Oral translation skills should be taught before going to translate any text.

- Instructors should concentrate on translation and interpretation activities which would increase interpreters' motivation. 
- Interpretation students should be given opportunities to express their feelings without fears in order to be balanced and qualified interpreters.

- Instructors should use technology to facilitate the sight translation process and any sort of oral translation.

- Some metacognitive strategies should be used widely in translation and interpretation classes.

\section{References}

Aeni, N., Jabu,B., Rahman,M., \& Strid,J., (2017). English Oral Communication Apprehension in Students of Indonesian Maritime . International Journal of English Linguistics; 7, (4) 158-165

Akbari, A. (2017). Needed skills and strategies to improve the efficiency of sight translation in classroom context. Trans-com, 10. Retrieved 12th September, 2017 from http:/www.transkom.eu/bd10nr01/transkom_10_01_02_Akbari_Sight.20170721 Al-Alwan, A., , Asassfeh, S., \& Yousef Al-Shboul, Y., (2013). EFL Learners' Listening Comprehension and Awareness of Metacognitive Strategies: How Are They Related?. International Education Studies, 6, ( 9) , 31-39 
Al-Otaibi, G. (2016). Speech anxiety among EFL Arab college students. Language in India,16(2), 83-100. $\mathrm{http}: / / \mathrm{www}$.languageinindia.com Amogne, D., \& Yigzaw, A. (2013). Oral communication apprehension, competence and performance among maritime engineering trainees. Journal of Media and Communication Studies, 5(1), 5.

Angelelli, C. (1999). The role of reading in sight translation. The ATA Chronicle (Translation Journal of the American Association of Translators), 28(5), 27-30

Birjandi, P., Mirhassani, A., \& Abbasian, G. (2006). Setting-based metacognitive strategy use. Journal of Faculty of Letters and Humanities, 49(198), 39-87.

Bond, D. (1984). Silent incarceration. Contemporary Education, 55(2), 95-101.

Brown,A.L.(1978). Knowing when, where, and how to remember : A problem of Metacognition. In R. Glaser (ED.), Advances in instructional psychology, Vol .1 (pp.77-165). Hillsdale :Eelbaum. Chamot, A. U., \& O'Malley, J. M. (1994). Language learner and learning strategies. In N. C. Ellis (Ed.), Implicit and explicit learning of languages (371-392). London: Academic 
Chang,K. (2016). Exploring Teaching /Learning Activities for Sight Translation :Effectiveness From Student Prospective.Taiwan Journal of TESOL 13(2):71-98.

Chen, I. J., \& Chang, C. C. (2009). Cognitive load theory: an empirical study of anxiety and task performance in language learning. Electronic Journal of Research in Educational Psychology, 7(2), 729-746. doi: 10.25115/ejrep.v7i18.1369

Ellis, R. (2005). The L2 motivational self-system, L2 anxiety, and motivated behavior: A structural equation modeling approach", in System, 38: 467-479.

Flavell, J. (1979). Metacognition and cognitive monitoring. American Psychologist. 34 (10), 906-911.

Friedman, P. (1980). Shyness and reticence in students (Analysis and action series). USA: National Education Association Publication.

Gonzalez , R.D ., Vasquez , V.F .,\& Mikkelson , H.(2012) . Fundamentals of Court Interpreting : Theory, policy, and practice .Durham : Carolina Academic press .

Holbrook, H. T. (1987). Communication apprehension: The quiet student in your classroom. ERIC Clearinghouse on Reading and Communication Skills Urbana IL. ERIC Digest. https://eric.ed.gov/?id=ED284315 
\begin{tabular}{|l|l|}
\hline \\
\hline
\end{tabular}

Horwitz, E. K. et al. (1991). Language Anxiety: From Theory and to Classroom Implications. Englewood Cliffs: Prentice-Hall, Inc.

Horwitz, E. K., Horwitz, M. B., \& Cope, J. (1986). Foreign language classroom anxiety. The Modern Language Journal, 70(2), 125-132. https://doi.org/10.1111/j.1540-4781.1986.tb05256.x

Idri, N. (2014). Fear of Negative Evaluation as a Variety of Anxiety in Foreign (Doctoral dissertation, Bejaia University).

Ilg, G., \& Lambert, S. (1996). Teaching consecutive interpreting. Interpreting, 1, 69-99.

Ireland, C. (2016). Student oral presentations: Developing the skills and reducing the apprehension. In Proceedings of 10th International Technology, Education and Development Conference Valencia, Spain. 79 March, 2016. IATED. IATED, Valencia, Spain, 1474-1483. http://eprints.hud.ac.uk/27264/

Ivars, A. J. (2008). Sight translation and written translation. A comparative analysis of causes of problems, strategies and translation errors within the PACTE translation competence model. Forum, 6(2), 79-103.

Krapivkina, O. (2015). Opposition of cultureoriented strategies in literary translation. European Journal of Social and Human Sciences, 3(7), 140-143.

Lambert, S. (2004): Shared attention during sight translation, sight interpretation and simultaneous interpretation. Meta. 49(2):294306. 
Lee, J. (2008) .Rating Scales for Interpreting Performance Assessment .The Interpreter and Translator Trainer 2 (2) 165-184 Lee, J. (2012). What skills do student interpreters need to learn in sight translation training? Meta: Journal des traducteurs, 57(3), 694-714.

Leong, L., \& Ahmadi, S. (2017). An analysis of factors influencing learners' English speaking skill. International Journal of Research in English Education, 2(1), 34-41. http://ijreeonline.com/article-138-en.html

Lu, H-C., Lu, H-L., \& Yen, A. (2003). A case study on teaching Chinese-Spanish on-line sight translation. Studies of Translation and Interpretation, 8, 245-281.

Matin, R. M. (2014). A Blurred Snapshot of Advances in Translation Process Research. MonTI Special Issue- Minding Translation: 49-84

McCroskey, J. C. (1980). On communication competence and communication apprehension: A response to page. Communication Education, 29, 109-111.

Nilsen, A. \& Monsrud,M. (2015): "Reading Skills for Sight Translation in Public Sector Services." The International Journal for Translation and Interpreting Research 7 (2)10-20

Noor, A., Rafek,M., Khalid, P., \& Mohammad, R., (2015) COMMUNICATION APPREHENSION IN LANGUAGE 


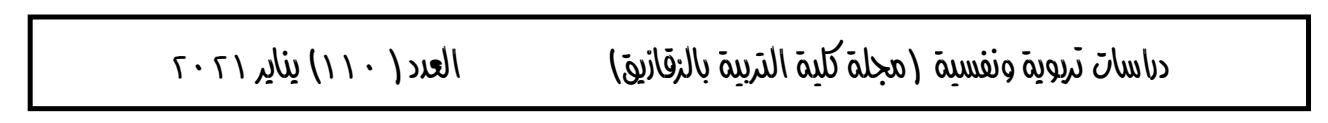

LEARNING: IS IT SERIOUS?. International Journal of Arts \& Sciences, 08(02), 311-320

O'malley, J. M., O'Malley, M. J., \& Chamot, A. U. (1990).Learning strategies in second language acquisition. Cambridge university press.

Peters, M. (2000). Does constructivist epistemology have a place in nurse education?. Journal of Nursing Education. Vol. 39 No. 4. pp. 166-70.

Pintrich, P. R. (2002). The role of metacognitive knowledge in learning, teaching, and assessing. Theory into practice, 41(4), 219225. http://dx.doi.org/10.1207/s15430421tip4104_3

Riccardi, Alessandra (2002):"Evaluation in Interpretation: Macrocriteria and Microcriteria." Eva Hung (ed.): Teaching Translation and Interpreting 4: Building Bridges. Amsterdam/ Philadelphia: Benjamins, 115-126

Richmond, V. P., \& McCroskey, J. C. (1995). Communication: Apprehension, avoidance, and effectiveness, (4th Ed). Scottsdale, AZ: Gorsuch Scarisbrick.

Rivers, W. (2001). Autonomy at all costs: an ethnography of metacognitive self-assessment and self-management among experienced language learners. Modern Language Journal. Vol. 85 No. 2. pp. 279-90. 
Taha , M., \& Abu Rezeq, Kh., (2018). Oral Communication Apprehension among English Senior Majors at Al-Quds Open University in Palestine. International Journal of Research in English Education , 3,(1), 44-58

Toth, Z. (2006). First-Year English Majors' Perceptions of the Effects of Foreign Language Anxiety on their Oral Performance. In M. Nikolov, J. Horvath (Eds.), UPRT 2006: Empirical Studies in English Applied Linguistics (pp. 25-39). Pecs: Lingua Franca Csoport.

Weber, K. (1984). Training translators and conference interpreters. New Jersey: Prentice Hall

Wenden, A. L. (1998). Metacognitive knowledge and language learning. Applied Linguistics, 19(4), 515-37.

Yahya, M. (2013). Measuring speaking anxiety among speech communication course students at the Arab American University of Jenin (AAUJ). European Social Sciences Research Journal, 1(3), 229-24 